\title{
Tertiary level English Language Teachers' Use of, and Attitudes to Alternative and Online Assessments during the Covid-19 Outbreak
}

\author{
Saud Mohammed Alenezi \\ English Language and Translation Department, Faculty of Education and Arts, Northern Border University, \\ Kingdom of Saudi Arabia
}

Received: March 17, 2021. Revised: November 11, 2021. Accepted: December 9, 2021. Published: January 5, 2022.

\begin{abstract}
This study aims to investigate the English language teachers' perceptions and attitudes towards the use of alternative and online assessments adopted during the Coronavirus (Covid-19) outbreak, in Saudi Arabia. The current study employs a descriptive method, and the data were collected using a survey questionnaire, which consists of 33 closed-ended and four open-ended questions. The participants were 102 (46 male and 56 female) teachers of English at Northern Border University, Saudi Arabia. The questionnaires were administered online via Google Form. The data were analyzed using descriptive statistics for quantitative responses, whereas content analysis was used to analyze the qualitative responses collected from the open-ended questions. The findings revealed that the teachers had mixed reactions towards alternative and online assessments. The online assessments adopted were in form of both alternative and traditional types, administered via Blackboard. It was found that portfolios and oral presentations were the most frequently used forms of alternative assessments by the English language teachers at the time of Covid-19. Other types of alternative assessments, including, online collaborative/peer assessment, self-assessment, virtual concept map, concept map, article review, and miniproject, were claimed to be less used by the teachers. However, the teachers' top priority was summative assessment, where by the traditional exams were in fact still be used in online assessment. In addition, teachers reported constraints related to time for the assessments, need for computer literacy, possibility of cheating, and technical issues, when adopting online assessments. However, they believed online assessment covered the content of the course of study. Teachers also reported that students did not initially like online assessment but later warmed to it as it proved easier to do well in. Finally, pedagogical implications are discussed based on the study findings.
\end{abstract}

Keywords-Alternative assessment, Covid-19, EFL context, English teachers, language skills, online assessment, traditional assessment.

\section{INTRODUCTION}

$\mathrm{T}$ HE sudden outbreak of Coronavirus (COVID-19) forced many countries to suspend traditional face-to-face education. However, to ensure the continuity of education, the Kingdom of Saudi Arabia (KSA) and many other countries shifted from traditional instruction to remote teaching. In the case of KSA, the Ministry of Education announced the suspension of face-to-face teaching and ordered all schools, colleges, and universities in the country to shift to remote learning [1]. This shift however aroused a major concerns regarding online systems of assessment adopted during the period.

It cannot be denied that assessment is essential in any educational system, as a means of determining educational success, and students' achievements [2]-[3]. Even before the Covid-19 outbreak, Saudi Arabia has introduced its national development program Saudi Vision 2030 and began implementing changes in all sectors including education. In line with that vision, it had launched various attempts to improve assessment techniques using alternative assessment methods which were believed to enhance the quality of the educational system [4].

Alternative assessment has also been the focus of many educational studies in EFL classroom [5]. According to [6], the Middle East and North Africa (MENA) regions have witnessed a sharp increase in the use of alternative forms of assessment across a number of subjects including EFL/ESL as a result of recent transformations of education systems. Up to 2020 however this had affected Saudi universities little and the official course specifications rarely required assessment in any form other than exams and quizzes, together with 'participation' and perhaps unspecified 'assignments'. However, as explained by [1] emergency remote teaching 
during the Covid-19 pandemic pressured teachers into some alternative assessment methods.

\section{LITERATURE REVIEW}

This section presents the conceptual and empirical literature review.

\section{A. Definition and types of educational assessment}

Assessment was defined by [7] as the systematic process of recording, evaluating knowledge, abilities, dispositions, or beliefs gleaned from instructional sequences. It has many types and purpose of which we review only the most relevant here.

- Formative and summative assessment

Whether learning is face to face or online, two major functional types of assessment are often distinguished: formative and summative. Formative assessment (aka assessment for learning) typically occur during a course, and is supposed to be used to provide learners with information about their ongoing learning progress and so help them guide their learning processes [8]. It can also provide teachers with information they can use to guide later teaching and decision making [9].

On the other hand, summative assessment (assessment for accreditation and validation) is used to provide learners' cumulative evaluation at end of learning courses. Its feedback is given in the form of scores or grades [8].

\section{- Traditional and alternative assessment}

Assessment can also be viewed as either traditional assessment or alternative assessment. Multiple choice tests, true-false tests, matching tests, fill-in-the-blank tests, short answer tests and essays are the most commonly used traditional assessment instruments. They are set and marked by examiners or, in KSA universities, the course teachers, and typically are delivered in formal exam conditions and yield numerical scores. These forms of assessment however suffer from drawbacks including lack of connection with the realistic conditions where the students need to use what they have learned, assessing only the product not the process of student performance, inability to assess students' higher-order thinking skills, attitudes, and other abilities that often among the objectives of a university course but cannot be quantified easily [10].

On the other hand, alternative assessment includes some methods adopted to cover the drawbacks of traditional assessment. It is difficult to find an inclusive definition of alternative assessment, but in the field of education, it is widely viewed as a broad range of assessment methods that generally oppose traditional assessment [5]. In other words, alternative assessment was described by [11] as an ongoing process that involves both students and teachers in making decisions on the progress of the students by non-conventional strategies. The most widely used types of alternative assessment in the field of language education include having students give oral presentations, do mini-projects, review articles, make concept maps, and using portfolios of students work, self-assessment, and collaborative/peer assessment [12].
According to [13], alternative assessment can improve learners' critical thinking, as it often involves ongoing interaction of the learner with the instructor. It does not take place in formal exam conditions, may target the process as well as the product of student performance (dynamic assessment), and 1 enables teachers to obtain a richer and more realistic view of the students' achievements.

\section{- Online assessment}

Online assessment is another dimension of assessment discussed, especially since the outbreak of Covid-19, and is widely used to systematically evaluate the online learning progress of learners for formative or summative purposes. In addition, it may be types, traditional or alternative type. Online courses are traditionally structured with summative assessments in place, such as exams, or collected portfolios [14]. Multiple choice tests are also popular because they can be scored automatically by computer. Whereas formative assessment is considered useful in the face-to-face classroom, there has been little review of how this form of assessment can be used in online learning modalities [15]. However, [8] argues that formative assessments are required just as much in the online classroom. Web-based alternative assessment (eassessment) can facilitate students and instructors in the process of collecting and assessing tasks.

Reeves [16] recommends using three aspect of alternative assessment in online learning environments. The first is for example concept mapping for cognitive assessment, which focuses on assessing higher-order thinking skills, and attitudes of students. The second method includes discussion and miniprojects for assessing learners' abilities to apply information, skill, and judgment in practical situations (performance assessment). The third method is portfolio assessment, which refers to collect students' work, over time and checking both the learning process and the product [17].

\section{B. Review of related studies}

Denman and Al-Mahrooqi [6] explored teachers' practices and attitudes in relation to alternative assessment in an English language foundation program at Sultan Qaboos University in Oman. Ten English language instructors responded to a questionnaire comprising 13 open-ended questions. Most participants perceived the usefulness of alternative assessment and believed it can promote learner independence. Some believed that alternative assessment develops students' vocabulary and reading comprehension, listening, grammar, and test-taking skills. However, they expressed concerns about cheating/copying, time requirements, and subjectivity of marking practices e.g., when teachers assess students' presentations or portfolio tasks. With regard to the possibility of cheating in online alternative assessment, [18] recommended that e-authentication systems should be used.

Demir, Tananis, and Trahan [12] conducted a systematic review of 42 educational research studies to investigate alternative assessment and how it is used. The analysis explored variables such as: method of the study, design, participants, area of the study, research context, and teachers' perceptions related to the use of alternative assessment approaches. The results showed that although some teachers may not feel qualified to use alternative assessments and need 
training, they still had positive attitudes towards this approach and believe that its techniques enhance higher-level thought and imagination.

However, there were no definite findings about the perceived success of alternative approaches in the summative role of assessment.

Monib, Karimi, and Nijat [5] discussed the different concepts, features and effects of alternative assessment specifically in EFL context by reviewing previous assessment research. Similar to the above, the results showed that most of the studies (18 out of 24) reported positive effects of using alternative assessment on language learning skills. For example, [19] study found that alternative assessment had significant effects on the participants' performance on the reading comprehension test. A study by [20] found that eportfolios increased the EFL learners' language quantity, and vocabulary knowledge. They also highlighted positive effects of using alternative assessment such as peer-feedback, and speaking portfolios in improving students' speaking skills.

In another study, [21] examined whether teachers' perceptions of alternative assessment methods differ depending on gender, years of experience, branch, and sufficient time to use alternative assessment methods. Participants in this study included 405 teachers from several schools and colleges in Turkey. The results showed variations in the attitudes of teachers towards alternative assessment methods due to in-service training, sufficiency of time to use such methods, field of study, and gender. Focusing more on the functions of summative assessments, teachers perceived alternative assessment approaches as unreliable due to problems of allocating enough time to use these approaches.

Kalra Sundrarajun, and Komintarachat [22] investigated the effects of portfolios on improving EFL learners writing skills. Fifty-six Thai undergraduate students who took an English for Business course at an International University in Thailand, participated in this study. Using a quasiexperimental approach, the participants were divided into experimental and control groups. The results of a paired sample t-test showed that the experimental group significantly outperformed the control group. However, the researchers admit (p.296) that the kind of portfolio model they implemented with the former group was for learning rather than for assessment. Indeed, it seems likely that a number of studies of alternative 'assessment' which improve, or are perceived to improve, student performance may involve uses of alternative procedures that do not actually include any assessment, such as [23].

In a more recent study, [24] investigated the digital portfolios to enhance EFL learners' speaking skill in higher education. Forty-two English major undergraduate students at Universidad Tecnica Particular de Loja, in southern Ecuador participated in this study. Digital portfolios were constructed by students. The researcher reported that digital portfolios were effective to enhance students' pronunciation and fluency. The results also showed that the introduction of digital portfolios can increase the motivation of students to practice oral skills in the target language. Here again, teachers gave feedback on the contents of the student portfolios, but it is unclear if they were really used for assessment and not simply as a teaching method or form of support for student practice.
Overall, then, EFL alternative assessment for typical summative purposes is often regarded as unreliable and whereas it is often seen as, or found to be, beneficial for learning when used formatively during a course, there is some doubt if such use always actually involves assessment at all. However, most studies of EFL alternative assessment do not document its use or teacher attitudes to it in online.

This study aims to fill these research gaps through exploring the beliefs and practices of EFL teachers at Northern Border University (NBU) in Saudi Arabia, in respect of online alternative assessment used during the Covid-19 pandemic.

\section{RESEARCH QUESTIONS}

For this study to achieve it aim, the following two questions are raised as follows:

1. What assessment, especially of alternative types, do English language teachers report prioritizing and using during the Covid-19 outbreak?

2. What are the teachers' perceptions about the benefits, requirements and problems of Online Assessment used during the Covid-19 outbreak?

\section{METHODS}

This descriptive study employs a survey to investigate EFL teachers reported use of and attitude to alternative and online assessments. In order to gather the best data possible to reveal the reality, it uses a mixed-methods design combining closed response questions with open response items. The participants were male and female English language teachers teaching English language in the Preparatory (pre-undergraduate) year or teaching English major undergraduates at four campuses (Arar , Rafiah, Turif \& Auegeelah) of Northern Border University, in Saudi Arabia. The questionnaires were distributed to 124 teachers and 102 completed questionnaires were returned, which represented $82 \%$ of the target participants. The sample size was acceptable since it represented more than $80 \%$ of the population as suggested by [25]. Table 1 describes the sample distribution.

Table 1. Demographic Information of the Respondents

\begin{tabular}{|c|c|c|c|}
\hline Division & Attribute & Number & Percentage \\
\hline \multirow{3}{*}{ Gender } & Male & 46 & $46 \%$ \\
\hline & Female & 56 & $54 \%$ \\
\hline & Total & 102 & $100 \%$ \\
\hline \multirow{4}{*}{$\begin{array}{l}\text { Years of } \\
\text { experience }\end{array}$} & 1 to 5 & 32 & $31.5 \%$ \\
\hline & 6 to 10 & 22 & $21.5 \%$ \\
\hline & 11 or above & 48 & $47 \%$ \\
\hline & Total & 102 & $100 \%$ \\
\hline \multirow{4}{*}{ Native language } & English native & 2 & $1.9 \%$ \\
\hline & Arabic native & 72 & $70.6 \%$ \\
\hline & Others & 28 & 27.5 \\
\hline & Total & 102 & $100 \%$ \\
\hline \multirow{4}{*}{$\begin{array}{c}\text { Expertise Level } \\
\text { in Teaching } \\
\text { Online }\end{array}$} & Low & 19 & $18.7 \%$ \\
\hline & High & 60 & $58.8 \%$ \\
\hline & Very High & 23 & $22.5 \%$ \\
\hline & Total & 102 & $100 \%$ \\
\hline
\end{tabular}




\section{A. The instrument and data collection procedure}

A questionnaire with thirty-three closed-ended questions, in the form of a five-point Likert scale, and four open-ended questions, was used in this study to measure the use and attitudes of English language teachers concerning alternative and online assessments employed during Covid-19 outbreak. The first dimension of the questionnaire contained six items about EFL teachers' priorities pertaining to the assessment types; the second dimension contained eight items focused on the alternative assessments used by the English Language Program during COVID-19; the third dimension contained five items related to EFL teachers' beliefs about alternative assessments, and the fourth dimension contained thirteen items related to EFL teachers' perceptions about on line assessment. In addition, the questionnaire contained four open-ended questions.

The researcher administered the questionnaire to $124 \mathrm{EFL}$ teachers at the two departments of English Language of Northern Border University in Saudi Arabia, via online using Google Forms, where 102 questionnaires were returned

\section{B. Analysis of the reliability and validity of the instrument}

The questionnaire instrument was sent to three experts of English language at the Department of English at the Northern Border University to ascertain face, content, and construct validity of the questions. In addition, to ascertain the reliability of the instrument, a pilot test was conducted with $20 \mathrm{EFL}$ teachers. The overall analysis of Cronbach's alpha $(\alpha)$ reliability for the pilot test was 0.91 , which indicated a very acceptable value.

Table 2. Cronbach's Alpha Test-Retest Reliability of the Four Dimensions of the Questionnaire

\begin{tabular}{|c|c|c|c|}
\hline Dimensions & Items & $\begin{array}{c}\text { Pilot 1st. } \\
\text { administered }\left(\alpha^{*}\right)\end{array}$ & $\begin{array}{c}\text { Pilot2nd. } \\
\text { Administered }\left(\alpha^{*}\right)\end{array}$ \\
\hline $\begin{array}{l}\text { Teachers' priorities } \\
\text { pertaining to } \\
\text { assessment }\end{array}$ & $\begin{array}{c}1,2,3,4,5 \\
6\end{array}$ & .90 & .91 \\
\hline $\begin{array}{l}\text { Alternative } \\
\text { assessments types } \\
\text { reported used in } \\
\text { English Department } \\
\text { programs during } \\
\text { COVID-19 }\end{array}$ & $\begin{array}{c}7,8,9,10, \\
11,12,13,14\end{array}$ & .89 & .90 \\
\hline $\begin{array}{l}\text { Teachers' beliefs } \\
\text { about the benefits of } \\
\text { alternative } \\
\text { assessment }\end{array}$ & $\begin{array}{c}15,16,17,18 \\
, 19\end{array}$ & .92 & .91 \\
\hline $\begin{array}{l}\text { Teachers' } \\
\text { perceptions of the } \\
\text { benefits, } \\
\text { requirements, } \\
\text { problems of online } \\
\text { assessment }\end{array}$ & $\begin{array}{c}20,21,22,23 \\
, 24,25,26,2 \\
7 \\
28,29,30,31 \\
, 32,33\end{array}$ & .88 & .92 \\
\hline
\end{tabular}

Cronbach's Alpha Reliability ( $\left.\alpha^{*}\right)$

As shown in Table 2, the items in all dimensions had acceptable Cronbach's alpha in both the first and the second questionnaire administrations for the pilot test, as suggested by [25], a measure is moderately reliable if its alpha is 0.70 or higher.

\section{Data analysis procedure}

A descriptive analysis was carried out to calculate the frequencies, percentages, means and standard deviations (SD) for each item of the four dimensions of the questionnaire using Statistical Package for Social Science (SPSS) version 25. On the other, content analysis was used to analyze the data collected from the open-ended questions qualitatively. Henceforth, the author adopted [26] multi-stage approach coding, which comprised eight stages. The eight phases that follow are listed below. (1) Immersion and identification of preliminary categories, (2) reaching consensus on categories by two evaluators, (3) checking the categories by the third evaluator, (4) allocating category and detail codes, (5) dealing with 'rogue' responses, (6) checking codes by the third evaluator, (7) merging and re-allocating codes, and finally, (8) checking the merging/re-allocating of codes by the third evaluator. This approach required at least three evaluators, two of whom worked closely together for most of the process, and a third researcher who performed a check on the acceptability of categories and the accuracy of subsequent coding were also required. The findings from quantitative and qualitative data were triangulated to provide the answer to the research questions.

\section{FINDINGS}

The author presents the findings in line with two research questions. To provide answers to the research questions, the findings from both quantitative descriptive analysis and qualitative content analysis were triangulated.

\section{Findings for Research Question 1}

What assessment, especially of alternative types, do English language teachers report prioritizing and using during the Covid-19 outbreak?

First of all, the findings with regard to research question 1, were presented using a descriptive analysis, and supported by the findings from qualitative content analysis. The author presents the results in two tables, the first table describes the English language teachers' priorities pertaining to assessments in general, whereas the second table shows their perceptions towards alternative form of assessments. 
Table 3. English language Teachers' Priorities Pertaining to Assessments

\begin{tabular}{|c|c|c|c|c|c|c|c|c|c|}
\hline Item & Statement & $\mathrm{f}$ & $\begin{array}{l}\text { Not a } \\
\text { priority }\end{array}$ & $\begin{array}{l}\text { Low } \\
\text { priority }\end{array}$ & $\begin{array}{l}\text { Medium } \\
\text { priority }\end{array}$ & $\begin{array}{l}\text { High } \\
\text { priority }\end{array}$ & Essential & Mean & $\mathrm{SD}$ \\
\hline 1 & $\begin{array}{l}\text { Traditional } \\
\text { (paper based, } \\
\text { one-shot tests) }\end{array}$ & $\begin{array}{l}\mathrm{N} \\
\%\end{array}$ & $\begin{array}{c}8 \\
7.8\end{array}$ & $\begin{array}{c}15 \\
14.7\end{array}$ & $\begin{array}{c}50 \\
49.0\end{array}$ & $\begin{array}{c}29 \\
28.4\end{array}$ & $\begin{array}{c}0 \\
0.0\end{array}$ & 2.98 & 0.867 \\
\hline 2 & $\begin{array}{l}\text { Alternative } \\
\text { (ongoing } \\
\text { assessment of } \\
\text { student } \\
\text { progress with } \\
\text { authentic } \\
\text { materials) }\end{array}$ & $\begin{array}{l}\mathrm{N} \\
\%\end{array}$ & $\begin{array}{c}2 \\
2.0\end{array}$ & $\begin{array}{c}12 \\
11.8\end{array}$ & $\begin{array}{c}33 \\
32.4\end{array}$ & $\begin{array}{c}55 \\
53.9\end{array}$ & $\begin{array}{c}0 \\
0.0\end{array}$ & 3.38 & 0.771 \\
\hline 3 & $\begin{array}{l}\text { Online (doing } \\
\text { tasks online } \\
\text { and getting } \\
\text { feedback } \\
\text { online) }\end{array}$ & $\begin{array}{l}\mathrm{N} \\
\%\end{array}$ & $\begin{array}{c}3 \\
2.9\end{array}$ & $\begin{array}{c}19 \\
18.6\end{array}$ & $\begin{array}{c}41 \\
40.2\end{array}$ & $\begin{array}{c}38 \\
37.3\end{array}$ & $\begin{array}{c}1 \\
1.0\end{array}$ & 3.15 & 0.837 \\
\hline 4 & $\begin{array}{l}\text { Formative } \\
\text { assessment } \\
\text { comprising } \\
\text { peer/critic } \\
\text { review and } \\
\text { discussion. }\end{array}$ & $\begin{array}{l}\mathrm{N} \\
\%\end{array}$ & $\begin{array}{c}3 \\
2.9\end{array}$ & $\begin{array}{c}16 \\
15.7\end{array}$ & $\begin{array}{c}33 \\
32.4\end{array}$ & $\begin{array}{c}49 \\
48.0\end{array}$ & $\begin{array}{c}1 \\
1.0\end{array}$ & 3.28 & 0.849 \\
\hline 5 & $\begin{array}{l}\text { Summative } \\
\text { assessment at } \\
\text { the end of the } \\
\text { course. }\end{array}$ & $\begin{array}{l}\mathrm{N} \\
\%\end{array}$ & $\begin{array}{c}3 \\
3.9\end{array}$ & $\begin{array}{c}12 \\
11.8\end{array}$ & $\begin{array}{c}28 \\
27.5\end{array}$ & $\begin{array}{c}58 \\
56.9\end{array}$ & $\begin{array}{c}0 \\
0.0\end{array}$ & 3.40 & 0.843 \\
\hline 6 & $\begin{array}{l}\text { Dynamic } \\
\text { assessment } \\
\text { (focus on the } \\
\text { process of } \\
\text { students' } \\
\text { mastering skills } \\
\text { rather than on } \\
\text { products) }\end{array}$ & $\begin{array}{l}\mathrm{N} \\
\%\end{array}$ & $\begin{array}{c}2 \\
2.0\end{array}$ & $\begin{array}{c}11 \\
10.8\end{array}$ & $\begin{array}{c}36 \\
35.3\end{array}$ & $\begin{array}{c}53 \\
52.0\end{array}$ & $\begin{array}{c}0 \\
0.0\end{array}$ & 3.37 & 0.757 \\
\hline
\end{tabular}

Table 3, showed that EFL teachers gave highest priority $(M=3.4)$ to summative assessment at the end of the course, which is not surprising given that the university requires it, in normal times before the Covid-19, usually implemented by a traditional final exam. However, slight disagreement $(M=2.98)$ and lowest priority was afforded to traditional paper-based tests, showing recognition that in the Covid-19 conditions the customary final exam administered on campus was not possible. The alternative assessment possibilities (items 2, 3, $4,6)$ all received endorsement above the middle of the scale (3), but most notably continuous assessment with focus on the process (item $2 M=3.38$, item $6 M=3.37$ ), such as portfolio assessment would involve. Possibly, it was recognized that this could cumulatively produce a required valid summative assessment as well as having formative value. By contrast, items 3 and 4, which focused on feedback, were less endorsed by the EFL teachers, the former perhaps because of the amount of extra work teacher feedback online would involve, the latter perhaps because of doubts about the reliability of peer review for assessment purposes. Furthermore, in fact neither would straightforwardly yield a summative mark/grade for the course.

The author further examines the types of alternative assessment used in English language program at the Northern Border University, in Saudi Arabia. The findings were presented in the table 4 below.
Table 4. Types of Alternative Assessment Used in the English Program during Covid-19

\begin{tabular}{|c|l|l|c|c|c|c|c|c|c|}
\hline Item & Statement & $\mathrm{f}$ & Never & $\begin{array}{c}\text { Almost } \\
\text { never }\end{array}$ & Occasionally & $\begin{array}{c}\text { Almost } \\
\text { every } \\
\text { time }\end{array}$ & $\begin{array}{c}\text { Every } \\
\text { time }\end{array}$ & Mean & SD \\
\hline 7 & Virtual oral & $\mathrm{N}$ & 6 & 12 & 36 & 26 & 22 & 3.45 & 1.131 \\
& presentation & $\%$ & 5.9 & 11.8 & 35.3 & 25.5 & 21.6 & & \\
\hline 8 & Portfolio & $\mathrm{N}$ & 13 & 20 & 16 & 43 & 10 & 3.17 & 1.121 \\
& & $\%$ & 12.7 & 19.6 & 15.7 & 42.2 & 9.8 & & \\
\hline 9 & Mini-project & $\mathrm{N}$ & 49 & 20 & 7 & 16 & 10 & 2.20 & 1.015 \\
& & $\%$ & 48.0 & 19.6 & 6.9 & 15.7 & 9.8 & & \\
\hline 10 & Article review & $\mathrm{N}$ & 32 & 24 & 16 & 23 & 7 & 2.50 & 1.158 \\
& & $\%$ & 31.4 & 23.5 & 15.7 & 22.5 & 6.9 & & \\
\hline 11 & Concept map & $\mathrm{N}$ & 16 & 41 & 19 & 21 & 5 & 2.59 & 1.09 \\
& & $\%$ & 15.7 & 40.2 & 18.6 & 20.6 & 4.9 & & \\
\hline 12 & Virtual concept & $\mathrm{N}$ & 17 & 38 & 22 & 17 & 8 & 2.62 & 1.151 \\
& map & $\%$ & 16.7 & 37.3 & 21.6 & 16.7 & 7.8 & & \\
\hline 13 & Self-assessment & $\mathrm{N}$ & 13 & 28 & 27 & 20 & 14 & 2.94 & 1.236 \\
& & $\%$ & 12.7 & 27.5 & 26.5 & 19.6 & 13.7 & & \\
\hline 14 & Online & $\mathrm{N}$ & 12 & 19 & 31 & 26 & 14 & 3.11 & 1.21 \\
& collaborative/ & $\%$ & 11.8 & 18.6 & 30.4 & 25.5 & 13.7 & & \\
\hline & peer assessment & & & & & & & & \\
\hline
\end{tabular}

Table 4, showed that only three types of the alternative assessments were claimed to be used on average more than occasionally (i.e., above the meddle rating of 3), by the EFL teachers. The most popular was an oral presentation $(\mathrm{M}=$ 3.45) given live online typically via Blackboard. This could readily be used either for formative or summative assessment of a speaking course or many subject content courses e.g. in sociolinguistics or English renaissance poetry. Second $(\mathrm{M}=$ 3.17) came portfolios, supporting what was explained above. These can be used for any kind of course, since they can contain samples of whatever work a student does on course. However, we must recognized that although portfolios are regarded as an alternative form of assessment, they may contain work that is not alternative in nature, such as, in the KSA context, multiple choice quizzes which are commonly given online during Covid-19 outbreak. Third, $(\mathrm{M}=3.11)$ came peer collaboration and assessment. This is somewhat surprising given what we said above, but it is possible that the teachers evaluating it as a learning strategy rather than really as a mean of assessing the learners.

Rather less claimed to be used were the five other types of alternative assessment. Self-assessment $(\mathrm{M}=2.94)$ only just fell short of occasional use on average. This is probably teachers who used it did so for its learning value in developing their ability of judging objectivity their work to develop their work rather than as assessment proper, since the university's regulations may not accept summative cause assessments including self-assessment by the students. The other types tended to fall in the "almost never" category. Genuine concept maps are little used in Saudi teaching and their use for assessment is even less well-known: it requires some training and skill to assess a genuine student concept mapping.

However, it is one of the major directions of alternative online assessment [16]. Also it would be very easy for concept mapping to become simply an occasion for presenting students 
with a model map for them to rote learn, which then is no longer an 'alternative' activity Article review and mini-projects are largely limited to assessing subject content classes for students at higher levels of English ability and subject knowledge.

The open response data relevant to research question 1, provided very important information complementing the picture above. Essentially, it showed that a great deal of assessments used by EFL teachers during Covid-19 in fact were not of alternative type. The findings of qualitative analysis under the theme Assessment Techniques, indicated that traditional quizzes, mid-term and final exams were continuously used. One of the teachers stated that he assessed:

By asking multiple choice type questions and sometimes by asking true and false questions.

[Participant 84, M]

Another respondent added classroom participation as a means of students' assessment:

Students are assessed through quizzes, assignments and class participation.

Another described the delivery:

$$
\text { [Participant 87, F] }
$$

My students are assessed by various methods and techniques instantly by utilizing 'BlackBoard' application...

[Participant 81, M]

On campus paper-based exam which covered writing and reading courses was another form of assessment used by some teachers, even during Covid-19.

Our students were asked to take face-to-face paperbased exam during mid-term and final exams for writing and reading courses.

[Participant 17, M]

There was also some mention of alternative assessment such as e-portfolios for speaking and writing tasks.

For example, one of the teachers stated that:

We adopt various means of conducting the assessment, we sometimes give e-portfolios, and online speaking tasks.

\section{[Participant 8, F]}

\section{Findings for Research Question 2}

What are the teachers' perceptions about the benefits, requirements and problems of Online Assessment used during the Covid-19 outbreak?

In this section the author first examines the teachers' attitudes towards alternative assessments which, as we noticed in the previous section, were in form of oral presentations, portfolios of whatever work students did during a course. In this regard, the author starts by presenting the descriptive analysis regarding EFL teachers' beliefs about the benefits of alternative assessments as shown in table 5 below.
Table 5. EFL Teachers' Beliefs about the Benefits of Alternative Assessments

\begin{tabular}{|c|c|c|c|c|c|c|c|c|c|}
\hline Item & Statements & f & 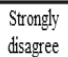 & Disagree & Undecided & Agree & $\begin{array}{c}\text { Strongly } \\
\text { agree }\end{array}$ & Mean & $S D$ \\
\hline 15 & $\begin{array}{l}\text { I think online } \\
\text { alternative } \\
\text { assessment is more } \\
\text { suitable to assess } \\
\text { English language } \\
\text { and teaching skills. }\end{array}$ & $\begin{array}{l}N \\
\%\end{array}$ & $\begin{array}{c}17 \\
16.7\end{array}$ & $\begin{array}{c}32 \\
31.4\end{array}$ & $\begin{array}{c}18 \\
17.6\end{array}$ & $\begin{array}{l}24 \\
23.5\end{array}$ & $\begin{array}{c}11 \\
10.8\end{array}$ & 2.80 & 1.275 \\
\hline 16 & $\begin{array}{l}\text { Alternative } \\
\text { assessmentis more } \\
\text { likely to yield } \\
\text { information that can } \\
\text { be used to improve } \\
\text { my teaching } \\
\text { practices. }\end{array}$ & $\begin{array}{l}N \\
\%\end{array}$ & $\begin{array}{c}5 \\
4.9\end{array}$ & $\begin{array}{c}20 \\
19.6\end{array}$ & $\begin{array}{c}18 \\
17.6\end{array}$ & $\begin{array}{c}44 \\
43.1\end{array}$ & $\begin{array}{c}15 \\
14.7\end{array}$ & 3.43 & 1.113 \\
\hline 17 & $\begin{array}{l}\text { Alternative } \\
\text { assessmentis more } \\
\text { likely to increase } \\
\text { learners' motivation } \\
\text { to learn English. }\end{array}$ & $\begin{array}{l}\mathrm{N} \\
\%\end{array}$ & $\begin{array}{l}10 \\
9.8\end{array}$ & $\begin{array}{c}18 \\
17.6\end{array}$ & $\begin{array}{c}18 \\
17.6\end{array}$ & $\begin{array}{c}37 \\
36.3\end{array}$ & $\begin{array}{c}19 \\
18.6\end{array}$ & 3.36 & 1.249 \\
\hline 18 & $\begin{array}{l}\text { Alternative } \\
\text { assessmentis more } \\
\text { likely to decrease } \\
\text { learners' anxiety to } \\
\text { learn English. }\end{array}$ & $\begin{array}{l}\mathrm{N} \\
\%\end{array}$ & $\begin{array}{c}7 \\
6.9\end{array}$ & $\begin{array}{c}25 \\
24.5\end{array}$ & $\begin{array}{c}19 \\
18.6\end{array}$ & $\begin{array}{c}33 \\
32.4\end{array}$ & $\begin{array}{c}18 \\
17.6\end{array}$ & 3.29 & 1.215 \\
\hline 19 & $\begin{array}{l}\text { Alternative } \\
\text { assessment is more } \\
\text { likely to promote } \\
\text { learners' English } \\
\text { language } \\
\text { proficiency. }\end{array}$ & $\begin{array}{l}\mathrm{N} \\
\%\end{array}$ & $\begin{array}{c}9 \\
8.8\end{array}$ & $\begin{array}{c}16 \\
15.7\end{array}$ & $\begin{array}{c}29 \\
28.4\end{array}$ & $\begin{array}{c}30 \\
29.4\end{array}$ & $\begin{array}{c}18 \\
17.6\end{array}$ & 3.31 & 1.194 \\
\hline
\end{tabular}

Table 5, showed that four of the five benefits that were asked about were agreed (above 3) to exist for alternative assessment (in implied contrast with traditional assessment). The top scoring benefit was providing information to help the teacher with his/her teaching $(M=3.43)$, a formative function which we saw was also emphasized in the literature. The others were enhancing student motivation $(M=3.36)$, proficiency $(M=3.31)$ and anxiety reduction $(M=3.29)$.

What is noticeable, then, is that the only proposition that was (mildly) disagreed with $(M=2.80)$ was item 15 , that alternative assessment (online) was better for assessing the students. In other words the teachers seem to reflect the same paradox seen in the literature that what is called alternative 'assessment' is in fact regarded as valuable as a teaching method or learning strategy to help students but, despite its name, not so much for assessment. This presumably arises from its essentially formative nature whereas most teachers associate assessment more strongly with summative functions.

Moreover, the EFL teachers' attitudes to online assessments were further elicited with implicit comparison with pre-Covid-19 live assessment on Campus. In this regards, the descriptive analyses of 14 items of the questionnaire were presented in the Table 6 below. 
Table 6. EFL Teachers' Perceptions of the Benefits,

Requirements and Problems of Online Assessments

\begin{tabular}{|c|c|c|c|c|c|c|c|c|c|}
\hline$m$ & Surems & $\mathrm{f}$ & Sxedt these & Diugs: & Untasides & $\operatorname{seg}$ & Smody yes & Lem & 50 \\
\hline$\sqrt{2}$ & 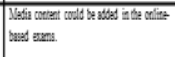 & $x$ & 1.0 & 69 & $\begin{array}{l}13 \\
127\end{array}$ & $\begin{array}{l}47 \\
4.1\end{array}$ & $\begin{array}{l}34 \\
313 \\
33\end{array}$ & 4,4 & 0911 \\
\hline II & 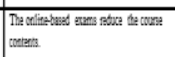 & $\begin{array}{ll}\pi \\
4\end{array}$ & $\begin{array}{l}10 \\
9.8\end{array}$ & $\begin{array}{l}85 \\
245\end{array}$ & $\begin{array}{r}24 \\
235\end{array}$ & $\begin{array}{l}34 \\
333\end{array}$ & is & 307 & 11.34 \\
\hline 2 & 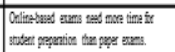 & $\begin{array}{ll}\pi \\
4\end{array}$ & $\begin{array}{l}\text { II } \\
\text { las }\end{array}$ & $\begin{array}{ll}37 \\
333\end{array}$ & $\begin{array}{l}16 \\
15.7\end{array}$ & $\begin{array}{l}24 \\
235\end{array}$ & $\begin{array}{l}14 \\
1.2\end{array}$ & 298 & 1281 \\
\hline 23 & 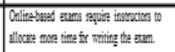 & $\frac{\pi}{4}$ & 19 & $\begin{array}{l}73 \\
215\end{array}$ & $\frac{11}{216}$ & $\begin{array}{l}38 \\
153\end{array}$ & $\begin{array}{l}17 \\
116\end{array}$ & 315 & 1.316 \\
\hline 24 & 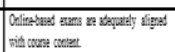 & $\begin{array}{l}1 \\
4 \\
4\end{array}$ & 6 & $\begin{array}{l}15 \\
147\end{array}$ & $\begin{array}{l}25 \\
25\end{array}$ & $\begin{array}{ll}4 \\
4: 1\end{array}$ & $\frac{18}{18}$ & 139 & L.M \\
\hline 25 & 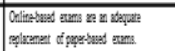 & $\begin{array}{ll}\pi \\
3 \\
3\end{array}$ & $\begin{array}{l}30 \\
24\end{array}$ & $\begin{array}{ll}12 \\
118\end{array}$ & 3 & $\begin{array}{l}16 \\
15.7\end{array}$ & $\begin{array}{l}5 \\
4 \\
49\end{array}$ & 2.55 & 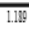 \\
\hline 8 & 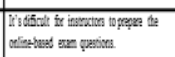 & $\begin{array}{l}1 \\
y \\
4\end{array}$ & $\begin{array}{ll}15 \\
147\end{array}$ & $\begin{array}{l}15 \\
245\end{array}$ & $\begin{array}{l}21 \\
25\end{array}$ & $\frac{10}{10.6}$ & $\frac{19}{116}$ & 310 & 1938 \\
\hline 7 & 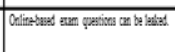 & $\begin{array}{ll}8 \\
4 \\
4\end{array}$ & $\begin{array}{l}\text { II } \\
\text { us }\end{array}$ & $\begin{array}{l}15 \\
147\end{array}$ & 14 & $\begin{array}{l}26 \\
155\end{array}$ & $\begin{array}{l}36 \\
313\end{array}$ & 3,60 & I.3. \\
\hline 3 & 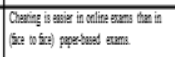 & $\begin{array}{l}\mathrm{x} \\
4 \\
4\end{array}$ & 49 & 118 & 28 & $\begin{array}{l}37 \\
363\end{array}$ & $\begin{array}{l}12 \\
11.8\end{array}$ & 3,31 & 10.0. \\
\hline$y$ & 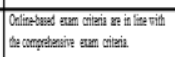 & $\begin{array}{ll} \\
3\end{array}$ & is & $\frac{12}{113}$ & $\begin{array}{ll}11 \\
176\end{array}$ & $\begin{array}{c}52 \\
5110\end{array}$ & $\begin{array}{l}14 \\
1.7\end{array}$ & 3.55 & 1058 \\
\hline 3 & 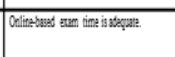 & $\begin{array}{ll}\pi \\
4\end{array}$ & 1. & $\begin{array}{ll}11 \\
10.8\end{array}$ & $\underbrace{8}_{106}$ & $\begin{array}{l}45 \\
4.1\end{array}$ & $\begin{array}{l}18 \\
45\end{array}$ & $3.0 \times$ & 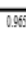 \\
\hline it & 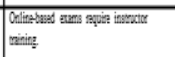 & $\begin{array}{ll}\pi \\
4\end{array}$ & dio & $\begin{array}{l}7 \\
18\end{array}$ & $\frac{11}{216}$ & $\begin{array}{ll}4 \\
402\end{array}$ & $\begin{array}{l}31 \\
31.4\end{array}$ & 3,155 & 0,06 \\
\hline in & 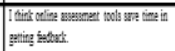 & $\frac{\pi}{3}$ & $\begin{array}{c}4 \\
39\end{array}$ & $\begin{array}{ll}\frac{18}{28} \\
235\end{array}$ & $\begin{array}{ll}32 \\
114\end{array}$ & $\begin{array}{l}y \\
324\end{array}$ & $\begin{array}{ll}\mathbb{1 1} \\
108\end{array}$ & 3.17 & 1.084 \\
\hline \# & 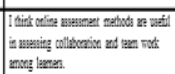 & $\begin{array}{l}1 \\
3 \\
4\end{array}$ & 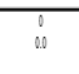 & $\begin{array}{l}119 \\
116\end{array}$ & $\begin{array}{l}4 \\
39\end{array}$ & $\begin{array}{l}28 \\
27.5\end{array}$ & $\begin{array}{l}51 \\
500\end{array}$ & 40 & 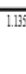 \\
\hline
\end{tabular}

Table 6, In interpreting this we must recall that, as seen above, for our teachers, online assessment did not include only alternative types, but also traditional quizzes and exams administered online via Blackboard. The items reported in table 6 are best considered in conjunction with themes discovered in the qualitative data from the open-ended questions.

\section{Time features}

A number of time-related aspects of online assessment were covered. With respect to preparation time, there was slight disagreement that students needed more time to prepare for online exams (item $22 \mathrm{M}=2.93$ ). There was however weak agreement (item $23 \mathrm{M}=3.15$ ) that teachers needed more time to write the exams. Possibly this referred to the extra time needed to put the exam into blackboard, over and above the usual time that would be required anyway to construct a live paper exam. Some teachers indicated that flexibility in when the assessment needed to be performed was a major strength of online assessments.
One teacher said:

I think the strength of this form of assessments is flexibility of timing.

[Participant 4, M]

Such flexibility would be more a feature of alternative assessment than traditional exams, however, responses to item $30(\mathrm{M}=3.80)$ endorsed the view that the length of the online time was adequate.

Another teacher referred to the speed of obtaining the results, which was also supported to some extent by item 32 $(\mathrm{m}=3.17)$ :

It is fast, whereby the students can get the immediate feedback.

\section{[Participant 81, M]}

Note that teachers here must have been thinking of traditional rather than alternative assessment, in the form of multiple-choice tests and the like, since only sort of assessment can be scored by computer online and give feedback instantly. Alternative assessment involving portfolios, for example, would not be at all fast, and oral presentations would not be scored by the teachers in online from any faster than when delivered live in a classroom.

\section{Simplicity and Ease}

Aside from time, ease more generally was mentioned.

Teachers responding to item 26 were neutral as to whether it was more difficult or not to prepare online exams questions $(\mathrm{M}=3.03)$. However other aspects were judged somewhat easier:

It is easier for the students to access their tests from home and to complete it on time.

\section{[Participant 8, F]}

It is easy to grade students' assignments, tests and exams.

[Participant 27, M]

\section{Content Coverage}

Another theme about online assessment is the content coverage. General responses to item $24(\mathrm{M}=3.33)$ supported the same view. Since the teachers themselves construct all assessment tasks and exams, this is of course not surprising. However, teachers responding to item 21 did not definitely reject the idea that the online exams reduced the course content $(\mathrm{M}=3.07)$. Possibly this refers to the sort of reduction that occurred in exams even before Covid-19 in that it is hard to claim that a multiple-choice exam can truly reflects the real intended content of the a course on applied linguistics or the $19^{\text {th }}$ century English novel.

In terms of content coverage of the teacher stated in the open-ended response:

It covers the syllabus, all aspects of the syllabus can be used during this kind of assessment, as done in the face-to-face on campus exam.

Another participant added that:

[Participant 27, M]

It covers all the elements of the contents.

[Participant 26, F] 
Another teacher however hinted that online assessment was superior, perhaps thinking of some alternative assessment types that she had included.

It helps to achieve all the course objectives.

\section{[Participant 39, F]}

Furthermore, closed item 20 suggested one area where online assessment definitely seemed to be superior in ability to cover content. Teachers agreed strongly $(\mathrm{M}=4.04)$ that media content could be added to the online exams. This presumably refers to a capability of Blackboard that allowed images, sounds, or videos to be included in traditional exams implemented online in that platform.

Language Skills and Students' Collaboration

Some of the teachers, presumably referring to oral assessments, reported that:

It improves their speaking skills as well as improve the discussion parts, teach them how to take responsibility in explaining to their colleagues.

\section{[Participant 50, F]}

In particular, with regard to the willingness to speak, one of the teachers said:

I think students are more willing to speak in the online class than in traditional settings because they feel no one is watching them.

[Participant 94, F]

Furthermore, overall the most favored closed item in Table 6 (33) confirms that view of alternative assessments online reported earlier, that it is valuable in relation to collaborative work $(\mathrm{M}=4.09)$. Here, then, the teachers seem to be again highlighting the value of alternative rather than traditional assessment online, albeit they are interpreting "assessment" more as a learning activity.

\section{Safety}

This is one of the emerging themes not covered by the closed-ended questions. Most of the teachers highlighted safety concerns as one of the advantages of online assessments.

It keeps students healthy safe while doing their exams

[Participant 27, M]

Most of what teachers said related to the above themes was favorable, some other comments were less so.

\section{Need for Computer Literacy}

Teachers reported that online assessment clearly, requires teachers to have knowledge of computers and relevant apps (e.g. Blackboard) in order to post assessments online, access and evaluate the students' assignments. As one teacher said:

Not much can be said about the weaknesses of online assessments, since the strengths outweigh them by far. But there might be some, for example, you need to be computer literate (or able to use a computer well) in order to create and take an assessment.

[Participant 90, M]

Consistent with this, teachers strongly agreed (item $31 \mathrm{M}=$ 3.95) that instructor training was required.

Possibility of Cheating and hence Unreliability of Results
More seriously, almost all of the teachers mentioned the tendency of students to cheat during online alternative assessment by receiving assistance from another person or copying from the Internet. For example, one of the teachers said:

These online assessments can lead to a lot of cheating among the students.

Another participant added that:

$$
\text { [Participant 8, F] }
$$

There is possibility of cheating and plagiarism.

[Participant 26, F]

As a consequence, another teacher mentioned that there is: Likelihood of cheating and of getting a mark without being sure that this was the student's own efforts.

[Participant 22, M]

Another stated more fully:

To my mind the major weakness of this type of assessment system is that "real" exam situation didn't prevail. Students could consult freely the Internet and their course materials, so I ended up with a lot of copy/paste passages.

[Participant 95, F]

Despite that, closed item $28(\mathrm{M}=3.31)$ cheating is easier in online exams" was not one of the items obtaining the highest agreement $(>4)$. Possibly then teachers saw cheating as more of a problem with alternative online assessment types rather than the traditional exams delivered online, since the later still had strict time limits which left little time for students to access the internet or other people when responding.

Even with exams however item $27(\mathrm{M}=3.60)$ showed considerable agreement that online exam questions could be leaked. This presumably refers to the fact that online exams were typically made available for long time, so those who take the exam earlier can in fact inform those who take it later of what the questions were before they start.

The learners are smart enough to overcome the obstacles and succeed in cheating.

[Participant 68, M]

\section{Technical issues}

Most of the teachers mentioned technical issues among the major defects of online forms of assessment. For example, one of the teachers listed internet issues:

Technical issues like login, audio, video and downloading or uploading issues.

Another teacher even reported that:

[Participant 52, F]

Some students don't have access to the Internet.

[Participant 39, F]

Student Acceptance of online assessment and Mixed Reactions

The teachers' views about online assessment were clearly influenced by their perceptions of the students' reactions to it. One of the teachers reported that:

Good students were excited about it but weak students were disappointed.

Another teacher argued that:
[Participant 35, M] 
Weaker students were reported to be frustrated with this form of assessments.

[Participant 35, M]

Some students displayed lackadaisical attitudes towards this form of assessment. For example, one of the teachers said:

They became very lazy and careless.

Another teacher added that:

$$
\text { [Participant 19, F] }
$$

They react with negligence and low motivation

[Participant 68, M]

Teachers also reported a negative novelty effect. The students showed dissatisfaction in accepting online assessments at the beginning, but later they adopted it: In the beginning? They were worried but then they became more familiar. Most of them like it.

[Participant 38, F]

Finally with regard to the students' satisfaction one of the teachers reported that:

They reacted to these techniques very comfortably because they got high marks and passed all the courses easily.

[Participant 24, M]

It appears likely then that some of teachers made the assessment in any case a little easier than usual in order to compensate for the fact that students had to deal with assessment delivered in a novel way, and indeed may have been stressed by the Covid-19 situation generally. However, some perhaps recognized that had weakened the validity of the assessment.

Overall, despite the broad range of views both negative and positive about online assessment, the teachers' overall judgment of whether online exams were an adequate replacement for paper-based exams was markedly negative (item $25 \mathrm{M}=2.55$, i.e., "disagree").

\section{DISCUSSION}

The focus of the present study was to examine EFL teachers' perceptions and attitudes towards the use of alternative and online assessments, adopted during the Covid19 emergency, in Saudi Arabia. This section discusses the findings of the study in relation to the previous studies. First of all, as aforementioned portfolio and virtual oral presentation were the most frequently used forms of alternative assessment reported by English teachers at the selected university during Covid-19. This is consistent with the top listed types of alternative assessment mentioned by [6] used at university in Oman before Covid-19. The present also that other types of alternative assess as listed by [12] were not used. Other types of alternative assessment seemed to be little used either because they would not be acceptable to the university as means of assessment (e.g. peer and self-assessment or because they were unfamiliar (e.g., concept map assessments) or not suited to students' level (e.g., mini-projects).

In this study, EFL teachers showed highest priority to summative assessment than other forms of assessment, which was largely covered by traditional exams as supported by [8], now delivered online. However, they valued alternative assessment when it was in form of formative assessment, where they seemed to treat it like a teaching/learning method rather than a true form of assessment. This echoed how it was viewed in some previous studies such as [21]-[5]. KSA is clearly among many countries where there is possibly overreliance on traditional exams for assessment and policy needs to move to favor a greater component of alternative methods such as continuous assessment by portfolios [9].

Concerning online assessment, EFL teachers in this study made both positive and negative points. However, all types of online assessment were judged excellent for Covid-19 safety, but unacceptably low in trustworthiness due to chances for students to cheat when taking online exams. The latter was similarly reported in Oman by [6]. It can be argued that long written assignments (i.e., mini-projects), including the text of an oral presentation and other alternative types of alternative assessment, can be plagiarized from the internet. Short or multiple-choices exam answers associated with summative assessment, crucial to the educational systems in most countries, can be Googled or obtained from others [18]. However, it can be suggested that the optimal solutions is raising the students' awareness regarding the plagiarism, full use of plagiarism detection software, and penalization of violations, this was consistent with suggestion given by [18] that advanced technological solutions are available but yet of little used. They included video recording or facerecognition of examinees as they are taking a computerbased test online, which however, for cultural reasons would not be acceptable for females in the KSA.

Another interesting findings regarding online assessment were related to time for the assessment, and content coverage. In this study, EFL teachers were found to be praising the online assessment for its speed and ease to manage. However, at the same time it was recognized that some teachers might need training to improve their digital literacy (e.g., in relation to facilities of online education platform such as Blackboard) and so make putting assessments online easier from them consistent with the findings of [21]-[1]. Flexibility of timing of taking an assessment was liked but has the downside mentioned above that it allows leakage of information between early takers and late takers of exams. Technical problems especially with the internet were widely recognized as disrupting ease of online assessment and need addressing. Content coverage was judged acceptable, at least in respect of use of alternative assessments online during Covid-19 outbreak, affecting speaking cooperative work among students, and in the ability to incorporate media in online exams. On the other hand, there was doubt as to whether the summative exams could be said really be claimed to really represent the course content fully. This probably was due to heavy reliance on closed items (e.g., multiple-choice) or short answer questions and this is an aspect of the exams in the university that needs diversification, for example, by incorporating into the final assessment grade more alternative assessment done earlier during the course.

Finally, teachers perceived that most of the students were eventually satisfied with the process of online assessment, although initially there was some nervousness. In agreements with [23] study, they were satisfied with their ability to follow their strengths, weakness and progress over the 
time through alternative assessment. As [8] claimed, formative alternative assessment can help students to see failure as a valuable component of the learning process and not as an outcome. On the other hand, some teachers reported that student satisfaction seemed to be simply a product of the exam being made easier in online, and argued that this will eventually make students lazy. The implication is that more steps need to be taken to maintain the validity of the online assessments.

\section{CONCLUSION}

Overall, assessment is regarded as a catalyst in the field of teaching and learning, therefore more attention was given by educators regarding the forms of assessment used during the emergency shifted from face-to-face teaching to online across the globe. This study reported the EFL teachers' perceptions regarding the alternative and online assessment adopted during the time of Covid-19. For pedagogical implications, the finding of this study can be used to improve the assessments techniques used in English language program at the university level. The teachers provided important information regarding the alternative and online assessments. This study suggested that EFL teachers need to be training on how to use a wider range of the known types of alternative assessment. In order to improve content coverage of the summative assessment, some reflection of the work done during the course involving alternative assessment needs to become part of the final grade (e.g. the best pieces of work from a portfolio). In addition, teachers should raise the students' awareness about the process of alternative online assessment to increase their satisfaction and engagement.

This study recommends that online alternative assessment should be continued in instruction after the Covid-19 period especially as a formative tool.

This study has some limitations, for example, the study consisted English language teachers from only one university in the KSA. However, the author believed that the finding will resonate in many universities in the Arab world and beyond where similar conditions are obtained. Future research is needed to further address the issues raised in this study concerning online assessment and alternative assessment types. It was also recommended to involve both students and teachers.

\section{References}

[1] Alqurshi, A. (2020). Investigating the impact of COVID19 lockdown on pharmaceutical education in Saudi Arabia-A call for a remote teaching contingency strategy. Saudi Pharmaceutical Journal, 28(9), 10751083.

[2] Khan, R. A., \& Jawaid, M. (2020). Technology enhanced assessment (TEA) in COVID 19 pandemic. Pakistan journal of medical sciences, 36(4), 108-111.

[3] Kearns, L.R. (2012). Student assessment in online learning: Challenges and effective practice". MERLOT Journal of Online Learning and Teaching. 8(3), 198-212.
[4] Alotabi, K. A. (2014). Student assessment strategies in Saudi Arabia: a case study of pre and post classroom practices. Literacy Information and Computer Education Journal (LICEJ), 3(1), 1786-1763.

[5] Monib, W. K., Karimi, A. Q., \& Nijat, N. (2020). Effects of alternative assessment in EFL classroom: A systematic review. American International Journal of Education and Linguistics Research, 3(2), 7-18.

[6] Denman, C., \& Al-Mahrooqi, R. (2018). Teachers' attitudes toward alternative assessment in the English language foundation program of an Omani University. In English Education in Oman (pp. 59-73). Springer, Singapore.

[7] Selma K., Xiongyi, L., Patrick, W. (2015). Assessment in online and blended learning environments. USA: Information Age Publishing Inc.

[8] Mohamadi, Z. (2018). Comparative effect of online summative and formative assessment on EFL student writing ability. Studies in Educational Evaluation, 59, 2940.

[9] Douglas, D. (2014). Understanding language testing. New York: Routledge.

[10] Franklin, J. (2002). Assessing assessment: Are alternative methods making the grade? Curriculum Update, www.ascd.org

[11] Hancock, C. R. 1994. Alternative assessment and second language study: What and why? Eric Digest, ED376695

[12] Demir, M., Tananis, C. A., \& Trahan, K. W. (2019). Evaluation of alternative assessment methods used in elementary schools. Egitim ve Bilim, 44(197), 223-238.

[13] Wubshet, H., \& Menuta, F. (2015). Investigating the practice of alternative assessment in English classrooms: The case of selected grade nine English teachers' assessment practices. International journal of scientific research in education, 8(4), 159-171.

[14] Bergquist, E., \& Holbeck, R. (2014). Classroom assessment techniques: A conceptual model for CATs in the online classroom. Journal of Instructional Research, 3, 3-7.

[15] Clark, I. (2012). Formative assessment: Assessment is for self-regulated learning. Educational Psychology Review, 24, 205-249.

[16] Reeves, T. C. (2000). Alternative assessment approaches for online learning environments in higher education: Journal of Educational Computing Research, 23(1), 101111.

[17] Knight, M. E (1994).Portfolio assessment: Application of portfolio analysis, University Press of America, Lanham, Maryland.

[18] Okada, A., Whitelock, D., Holmes, W., \& Edwards, C. (2019). E- authentication for online assessment: A mixed- method study. British Journal of Educational Technology, 50(2), 861-875.

[19] Aliasin, S., \& Amanlu, M. (2017). The effect of alternative assessment techniques on EFL learners' reading comprehension ability and self-efficacy in reading: The case of Iranian Junior High School students. Linguistics and Literature Studies, 5(3), 160168. 
[20] Safari, M., \& Koosha, M. (2016). Instructional efficacy of portfolio for assessing Iranian EFL learners' speaking ability. English Language Teaching, 9(3), 102-116.

[21] Kilmen, S., \& Kosterelioglu, I. (2017). Examination of teachers' perceptions towards alternative assessment approaches with CHAID Analysis. Elementary Education Online, 16 (1), 256-273.

[22] Kalra, R., Sundrarajun, C., \& Komintarachat, H. (2017). Using portfolio as an alternative assessment tool to enhance Thai EFL students' writing skill. Arab World English Journal (AWEJ) (8)4, 292-302.

[23] Tuvachit, V., \& Soontornwipast, K. (2018). Integrating adapted approaches of writing instructions with alternative assessment to improve academic writing ability. Arab World English Journal (AWEJ), 9(3), 188206.

[24] Cabrera-Solano, P. (2020). The use of digital Portfolios to enhance English as a foreign language speaking skills in higher education. International Journal of Emerging Technologies in Learning (iJET), 15(24), 159-175.

[25] Krejcie, R. V., \& Morgan, D. W. (1970). Determining sample size for research activities. Educational and psychological measurement, 30(3), 607-610.

[26] Nunnally, J. C., \& Bernstein, I. H. (1994). Psychometric theory (3rd Ed.). New York: McGraw-Hill.

[27] Hickey, G., \& Kipping, C. (1996). A multi-stage approach to the coding of data from open-ended questions. Nurse researcher, 4(1), 81-91.

\section{Creative Commons Attribution License $\mathbf{4 . 0}$ (Attribution 4.0 International, CC BY 4.0) \\ This article is published under the terms of the Creative Commons Attribution License 4.0 \\ https://creativecommons.org/licenses/by/4.0/deed.en_US}

